\title{
Preparation of a New Solid-State Molybdenum-Selective Electrode and Application
}

\author{
Şükrü Kalayci \\ Department of Chemistry, Gazi University, Ankara, Turkey \\ Email: skalayci@gazi.edu.tr
}

How to cite this paper: Kalayci, Ş. (2020) Preparation of a New Solid-State Molybdenum-Selective Electrode and Application. American Journal of Analytical Chemistry, 11, 221-231.

https://doi.org/10.4236/ajac.2020.115018

Received: April 5, 2020

Accepted: May 19, 2020

Published: May 22, 2020

Copyright $\odot 2020$ by author(s) and Scientific Research Publishing Inc. This work is licensed under the Creative Commons Attribution International License (CC BY 4.0).

http://creativecommons.org/licenses/by/4.0/

\section{(c) (i) Open Access}

\begin{abstract}
A new solid state molybdenum-selective electrode has been developed. The electrode is composed of $20 \% \mathrm{MoS}_{2}, 60 \% \mathrm{Ag}_{2} \mathrm{~S}$, and $20 \% \mathrm{Cu}_{2} \mathrm{~S}$. An analytically useful potential change occurred, from $1 \times 10^{-5}$ to $1 \times 10^{-1} \mathrm{M}$ molybdenum ion. The slope of the linear portion $\left(1 \times 10^{-1}-1 \times 10^{-5} \mathrm{M}\right)$ was about $45 \pm 2$ $\mathrm{mV} / 10$-fold concentration changes in molybdenum. It was found that $\mathrm{pH}$ change between 1 and 12 had no effect on the potential of the electrode. There was no interference of most common cations such as $\mathrm{K}^{+}, \mathrm{Na}^{+}, \mathrm{Ca}^{2+}$, $\mathrm{Mg}^{2+}, \mathrm{Cu}^{2+}$ and $\mathrm{Fe}^{3+}$ anions such as $\mathrm{Cl}^{-}, \mathrm{NO}_{3}^{-}, \mathrm{SO}_{4}^{2-}$ and $\mathrm{PO}_{4}^{3-}$. The lifetime of the electrode was more than 2 years, when used at least $4-5$ times a day, and the response time was about $30 \mathrm{~s}$. This electrode has been used for the determination of molybdenum ion in wine using standard addition method. The validation of the electrode has been made with a commercial molybdenum DP polarography and high consistency was obtained.
\end{abstract}

\section{Keywords}

Molybdenum Electrode, Determination, Solid State Electrode, DP

Polarography, Spinach

\section{Introduction}

Molybdenum is found in trace amounts in living cells. It is an essential element for plants. It also acts as a catalyst in the nitrogen-binding process of bacteria in legumes. It is used in trace amounts in the nutrition of plants. Therefore, molybdenum determination is important.

A trace amount of molybdenum (VI) can be determined by using its catalytic effect on the oxidation of iodide to iodine by hydrogen peroxide in acidic me- 
dium. Addition of ascorbic acid added to the reaction mixture produces the Landolt effect; i.e. the iodine produced by the indicator reaction is reduced immediately by the ascorbic add. Hence the concentration of iodide begins to decrease once all the ascorbic acid has been consumed. The induction period is measured by monitoring the concentration of iodide ion with an iodide ion-selective electrode [1].

A new method for the determination of molybdenum and tungsten is described based on their catalysis of the hydrogen peroxide-iodide reaction as monitored with an iodide ion-selective electrode. This method yields better results than methods previously used. In the present work only $0.004 \mu \mathrm{g} / \mathrm{ml}$ of molybdenum and tungsten is determinable [2].

Another in study, a highly selective and sensitive monohydrogen phosphate membrane sensor based on a molybdenum bis(2-hydroxyanil) acetylacetonate complex (MAA) is reported. The sensor shows a linear dynamic range between $1.0 \times 10^{-1}$ and $1.0 \times 10^{-7} \mathrm{M}[3]$.

New $\mathrm{pH}$ and sodium ion-sensitive metal-oxide-type sensors have been developed and tested with a direct solid state contact method. Performance was demonstrated at ambient temperature with single crystals of several molybdenum bronzes (i.e. $\mathrm{Na}_{0.9} \mathrm{Mo}_{6} \mathrm{O}_{17}, \mathrm{Li}_{0.9} \mathrm{Mo}_{6} \mathrm{O}_{17}, \mathrm{Li}_{0.33} \mathrm{MoO}_{3}$ and $\mathrm{K}_{0.3} \mathrm{MoO}_{3}$ ). The $\mathrm{pH}$ sensors with $\mathrm{Na}$-molybdenum-oxide bronzes show near ideal Nernstian behavior in the $\mathrm{pH}$ range 3 - 9 [4].

A new polymeric membrane electrode (PME) and a coated platinum disk electrode (CPtE) based on Schiff base complex of $\mathrm{Mo}(\mathrm{VI})$ as a suitable carrier for $\mathrm{I}^{-}$ion were described [5].

Three-dimensional (3D) molybdenum sulfidenan of lowers have been synthesized via a novel hydrothermal method and applied as ion-to-electron transducer for solid-contact ion-selective electrodes [6].

A new selenite ion selective electrode using solid salts of $\mathrm{Ag}_{2} \mathrm{Se}$ and $\mathrm{Cu}_{2} \mathrm{~S}$ has been developed. Detailed information is provided concerning the composition, working $\mathrm{pH}$ and conditioning of the electrode. The change of potential with concentration is found to be linear in the range of $10^{-5}-10^{-2} \mathrm{M}$; the slope of the linear portion is $28 \mathrm{mV} / 10$-fold change in selenite concentration [7].

A solid-state ion selective electrode, which is sensitive to hydroxide ion concentration has been prepared. This electrode with a $10 \% \mathrm{Cu}_{2} \mathrm{~S}$ and $90 \% \mathrm{Ag}_{2} \mathrm{Se}$ composition exhibited an analytically useful potential change from $10^{-6}$ to $10^{-1}$ $\mathrm{M}$ hydroxide ion, $\mathrm{pH} 8$ - 13. The slope of linear portion is about $58 \mathrm{mV}$ per decade change in hydroxide concentration [8].

A new solid state fluoride ion selective electrode composed of $70 \% \mathrm{Ag}_{2} \mathrm{~S}, 10 \%$ $\mathrm{Cu}_{2} \mathrm{~S}$ and $20 \% \mathrm{CaF}_{2}$ has been developed. An analytically useful potential change occurred, from $1 \times 10^{-6}$ to $1 \times 10^{-1} \mathrm{M}$ fluoride ion. The slope of the linear portion $\left(1 \times 10^{-1}-1 \times 10^{-5} \mathrm{M}\right)$ was about $26 \pm 2 \mathrm{mV} / 10$-fold concentration changes in fluoride [9].

A new borate ion selective electrode using solid salts of $\mathrm{Ag}_{3} \mathrm{BO}_{3}, \mathrm{Ag}_{2} \mathrm{~S}$ and $\mathrm{Cu}_{2} \mathrm{~S}$ has been developed. Detailed information is provided concerning the com- 
position, working $\mathrm{pH}$ and conditioning of the electrode. An analytically useful potential change occurred from $1 \times 10^{-6}$ to $1 \times 10^{-1} \mathrm{M}$ borate ion. The slope of the linear portion was $31 \pm 2 \mathrm{mV} / 10$-fold changes in borate concentration [10].

Using the DPP polarograms of wet digested cauliflower sample in acetate buffer at $\mathrm{pH}$ values of 2, 4 and 6, Fe, $\mathrm{Zn}, \mathrm{Mo}, \mathrm{Se}, \mathrm{Cr}, \mathrm{Cd}, \mathrm{Pb}, \mathrm{Ti}$ and $\mathrm{Cu}$ quantities were determined. The best separation and determination conditions for Mo were $\mathrm{pH} 2$ in acetate buffer. The Mo (VI) ranges for cauliflowers Mo $170-230$ $\mu \mathrm{g} \cdot \mathrm{g}^{-1}[11]$.

For the trace determination of elements in spinach a new differential pulse polarographic (DPP) method is established. Mo (VI) was determined at $\mathrm{pH} 4$ acetate buffer. Mo (VI) in spinach was found as $43 \mu \mathrm{g} / \mathrm{g}$ [12].

Mo and $\mathrm{V}$ are abundant trace elements in the environment and of great significance for many organisms. Their accurate and precise determination in natural waters by means of AAS and ICP-OES often requires a separation and/or a pre-concentration step. For the reliable and simple separation of Mo and V in the ng/L to $\mu \mathrm{g} / \mathrm{L}$ range, the co-precipitation on Cell-Fe and Cell-In can be applied with good reproducibility. By coupling with atomic spectroscopy, analytical procedures result for ultra trace determination of Mo and V, even in complex water matrices or biological fluids (e.g. urine) [13].

A new ultrasonic-thermostatic-assisted cloud point extraction procedure (UTA-CPE) was developed for preconcentration at the trace levels of vanadium (V) and molybdenum (Mo) in milk, vegetables and foodstuffs prior to determination via flame atomic absorption spectrometry (FAAS) [14].

Another in work a new procedure for the determination of ultra-trace concentrations of Mo in plants is proposed. The limit of detection of the analytical procedure was $260 \mathrm{pg} \cdot \mathrm{g}^{-1}$ [15].

The aim of this work was to fulfill this gap and to prepare an electrode selective for molybdenum ion which is easy to prepare, easy to handle and has long lifetime. In other methods, molybdenum determination is costly and requires pre-concentration. The most important advantage of this electrode is not being sensitive to other ions. The present work describes the preparation and application of a new solid state molybdenum ion selective electrode, which fulfills the above given futures. Molybdenum ion in spinach was analyzed with new electrode.

\section{Experimental}

\subsection{Apparatus and Reagents}

Potential measurements were made with a Jenway 3040 ion meter. All potential values reported, are taken with respect to an 924036 Double Junction $\mathrm{Ag} / \mathrm{AgCl}$ saturated reference electrode which was hold in a Luggin-Haber capillary. Reagent grade chemicals were used without further purification. All solutions were prepared with triple distilled water. For the preparation of $\mathrm{pH}$ buffers proper known solutions are used. 
Stock $0.1 \mathrm{M}$ solution of molybdenum was prepared by dissolving $5.14 \mathrm{~g}$ of $\mathrm{Na}_{2} \mathrm{MoO}_{4}$ (Merck pro analysis) in $250.0 \mathrm{ml}$ distilled water.

Preparation of $\mathrm{Ag}_{2} \mathrm{~S}$ : about $3 \mathrm{~g}$ of $\mathrm{AgNO}_{3}$ (Fluka) is dissolved in distilled water, $40 \mathrm{ml} 1 \mathrm{M} \mathrm{Na}_{2} \mathrm{~S}$ (Merck) is added. Precipitate formed is filtered, washed several times, dried in an oven at $110^{\circ} \mathrm{C}$. It was stored in a desiccator in dark.

Preparation of $\mathrm{Cu}_{2} \mathrm{~S}$ : to protect from air oxidation this reaction was carried out under nitrogen atmosphere. About $2 \mathrm{~g}$ of $\mathrm{CuCl}$ was dissolved in $100 \mathrm{ml}$ de-aerated water, in order to protect from oxidation. To this solution $\mathrm{Na}_{2} \mathrm{~S}$ prepared also with de-aerated water is added. It was left waiting for $30 \mathrm{~min}$ at $60^{\circ} \mathrm{C}$. Black precipitate formed is filtered, washed several times and dried in an oven at $110^{\circ} \mathrm{C}$. It was stored in a desiccator.

\subsection{Preparations of Electrodes}

Precipitated solid salts such as $\mathrm{MoS}_{2}, \mathrm{Ag}_{2} \mathrm{~S}$ and $\mathrm{Cu}_{2} \mathrm{~S}$ were dried and then mixed in varying compositions. A certain amount of the salt or salt mixture (10 - 15 $\mathrm{mg}$ ) was taken and pellets were made by holding first under a pressure of 5000 $\mathrm{kg} \cdot \mathrm{cm}^{-2}$ for $5 \mathrm{~min}$ and then under a pressure of $8000 \mathrm{~kg} \cdot \mathrm{cm}^{-2}$ for $10 \mathrm{~min}$ using the hydraulic press of IR instrument. The pellets of $7 \mathrm{~mm}$ diameter and $0.1-0.3$ $\mathrm{mm}$ thickness were sealed with epoxy resin ( $0.7 \mathrm{~g}$ epoxy and $0.9 \mathrm{~g}$ hardener).

To obtain a good sealing the epoxy resin ( $0.7 \mathrm{~g}$ epoxy $0.9 \mathrm{~g}$ hardener) on the edge of the tubing had to wait for about $10 \mathrm{~min}$ and then the pellet was sealed. One day after the pellet was sealed a silver wire with a flat end is connected. For this purpose, the inside of the glass tube was filled to about $1 \mathrm{~cm}$ with a mixture of $0.5 \mathrm{~g}$ graphite powder, epoxy resin and hardener. The electrode prepared had to wait for about 2 days so that the resin can get dry. The surface of the electrode is washed and then polished with a soft paper. These electrodes should wait in air and in a dark place when they are not in use. The lifetime of these electrodes can be at least 2 years, when they are used $4-5$ times a day.

\section{Result and Discussion}

\subsection{Calibration Curves of the Electrodes}

The potentiometric response of electrodes prepared in different compositions, were investigated against molybdenum ion concentration. For this purpose, appropriate spikes of molybdenum solution (prepared from $\mathrm{Na}_{2} \mathrm{MoO}_{4}$ ) were introduced to the cell and corresponding potentials were recorded. For a fixed ionic strength all measurements were made in $20 \mathrm{ml} 0.1 \mathrm{M} \mathrm{NaNO}_{3}$ solution. This is very important since during the formation of calibration curve or during standard additions the change in concentration will be 10 times.

The response of each molybdenum electrode was measured after the additions of $0.2 \mathrm{ml} \mathrm{Na}_{2} \mathrm{MoO}_{4}$ solutions so that molybdenum ion concentrations changed from $0.1 \mathrm{M}$ to $1 \times 10^{-6} \mathrm{M}$. For the calibration curve the potential readings were plotted against pMo concentration. The calibration curve for the electrode with the $20 \% \mathrm{MoS}_{2}, 60 \% \mathrm{Ag}_{2} \mathrm{~S}, 20 \% \mathrm{Cu}_{2} \mathrm{~S}$ composition is given in Figure 1 as an example. 


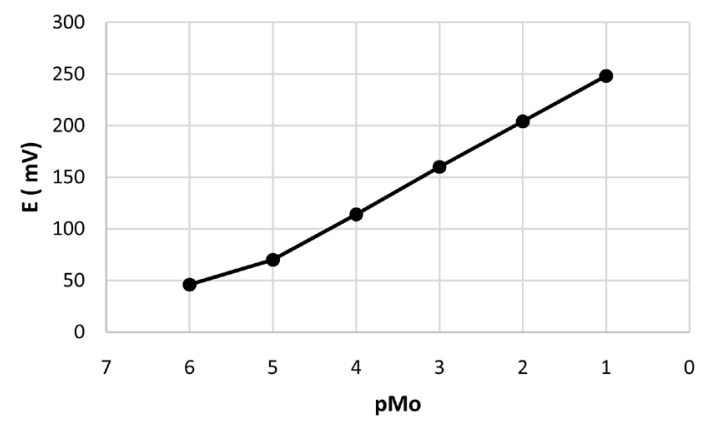

Figure 1. Calibration curve for the newly prepared molybdenum electrode (in $0.1 \mathrm{M}$ $\left.\mathrm{NaNO}_{3}\right)$. Response to $\mathrm{Na}_{2} \mathrm{MoO}_{4}$ standard additions $\left(20 \% \mathrm{MoS}_{2}, 60 \% \mathrm{Ag}_{2} \mathrm{~S}, 20 \% \mathrm{Cu}_{2} \mathrm{~S}\right)$.

As expected for anions, with increasing concentration of molybdenum ion the potential becomes more positive.

\subsection{Effect of Electrode Compositions and Thickness}

Membrane composition has a great effect over the sensitivity, selectivity and stability of the ion selective membrane electrodes. In this study, electrodes using $\mathrm{MoS}_{2}, \mathrm{Ag}_{2} \mathrm{~S}$ and $\mathrm{Cu}_{2} \mathrm{~S}$ in 4 different compositions were prepared in which the percentage of $\mathrm{MoS}_{2}$ varied from 30, 20, 10 and 5. Response of electrodes against the change molybdenum concentrations is given in Figure 2 and Table 1.

The highest slope was obtained for the electrode having 20\% $\mathrm{MoS}_{2}, 60 \% \mathrm{Ag}_{2} \mathrm{~S}$ and $20 \% \mathrm{Cu}_{2} \mathrm{~S}$ composition. The average slope for four electrodes, prepared in same composition, was $45 \pm 2 \mathrm{mV}\left(\mathrm{R}^{2}=0.9911\right)$ in $1 \times 10^{-5} \mathrm{M}-1 \times 10^{-1} \mathrm{M}$ molybdenum concentration range.

\subsection{Conditioning of Electrode}

The electrodes prepared in $20 \% \mathrm{MoS}_{2}, 60 \% \mathrm{Ag}_{2} \mathrm{~S}$ and $20 \% \mathrm{Cu}_{2} \mathrm{~S}$ composition were left in air (in dark), in distilled water and in $10^{-4} \mathrm{M} \mathrm{Na}_{2} \mathrm{MoO}_{4}$ solution under same duration of time and then their responses to molybdenum ion were measured. It was found that the electrode had a highest slope when it was used just after preparation or when it was left wait in air (in dark), when it was washed and wiped thoroughly after its usage. But when it was left wait in distilled water or in molydate solution the slope decreased drastically. The calibration curves obtained for various conditions are given in Figure 3.

\subsection{The Response Time}

The response time of the electrode depends on the concentration change. After each addition the time until the change in potential was constant is taken as the response time. When molybdenum concentration was changed from $1 \times 10^{-5}$ to $1 \times 10^{-4}$, from $1 \times 10^{-4}$ to $1 \times 10^{-3}$, from $1 \times 10^{-3}$ to $1 \times 10^{-2}$ and from $1 \times 10^{-2}$ to $1 \times 10^{-1} \mathrm{M}$, the response of the electrode was about $15-20 \mathrm{~s}$, which is a short period and it is an advantage. For this reason, this electrode can easily be used for routine analysis. All of these measurements were made at constant temperature and the electrode with the highest slope has been used throughout the work. 


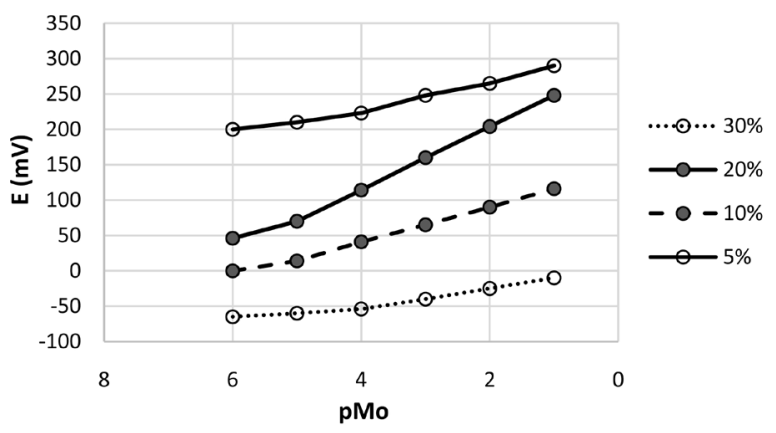

Figure 2. Calibration curves for molybdenum electrodes prepared of different compositions (the percentages belong to $\mathrm{Mo}_{2} \mathrm{~S}$ in electrode).

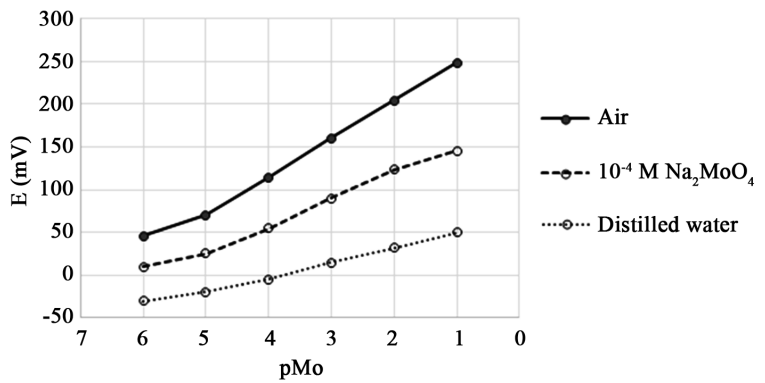

Figure 3. The effect of medium in which the electrode was stored $\left(20 \% \mathrm{MoS}_{2}, 60 \% \mathrm{Ag}_{2} \mathrm{~S}\right.$, $20 \% \mathrm{Cu}_{2} \mathrm{~S}$ ).

Table 1. Effect of composition on the response of electrode (potentials are measured against $\mathrm{Ag} / \mathrm{AgCl}$ reference electrode) (the percentages belong to $\mathrm{MoS}_{2}$ in electrode).

\begin{tabular}{ccccc}
\hline \multirow{2}{*}[\text{Mo(VI)}]{} & \multicolumn{5}{c}{$\mathrm{E}(\mathrm{mV})$} \\
\cline { 2 - 5 } $1 \times 10^{-6}$ & $30 \%$ & $20 \%$ & $10 \%$ & $5 \%$ \\
$1 \times 10^{-5}$ & -65 & 46 & 0 & 200 \\
$1 \times 10^{-4}$ & -60 & 70 & 14 & 210 \\
$1 \times 10^{-3}$ & -54 & 114 & 41 & 223 \\
$1 \times 10^{-2}$ & -40 & 160 & 65 & 248 \\
$1 \times 10^{-1}$ & -25 & 204 & 90 & 265 \\
Slope $\left(1 \times 10^{-6}-1 \times 10^{-1}\right)$ & -10 & 248 & 116 & 290 \\
Slope $\left(1 \times 10^{-5}-1 \times 10^{-1}\right)$ & $14 \pm 1$ & $40 \pm 2$ & $29 \pm 2$ & $18 \pm 1$ \\
\hline
\end{tabular}

\subsection{Effect of $\mathrm{pH}$}

Effect of $\mathrm{pH}$ on the potential readings in the presence of $10^{-3}$ molybdenum was investigated. For this purpose, to $20 \mathrm{ml} 0.1 \mathrm{M} \mathrm{NaNO}_{3}$ solutions $0.02 \mathrm{ml}$ aliquots of $1 \mathrm{M} \mathrm{HCl}$ was added and the potentials after each addition were measured. The same procedure was applied for the $\mathrm{NaOH}$ additions. The electrode with the highest slope $\left(20 \% \mathrm{MoS}_{2}\right)$ was used during the measurements. The change in potential with $\mathrm{pH}$ was only $2-3 \mathrm{mV}$ for each $\mathrm{pH}$ unit change from $\mathrm{pH} 1$ to 9 . As can be seen from Figure 4, the electrode can be used between pH 1 and 9 safety. 


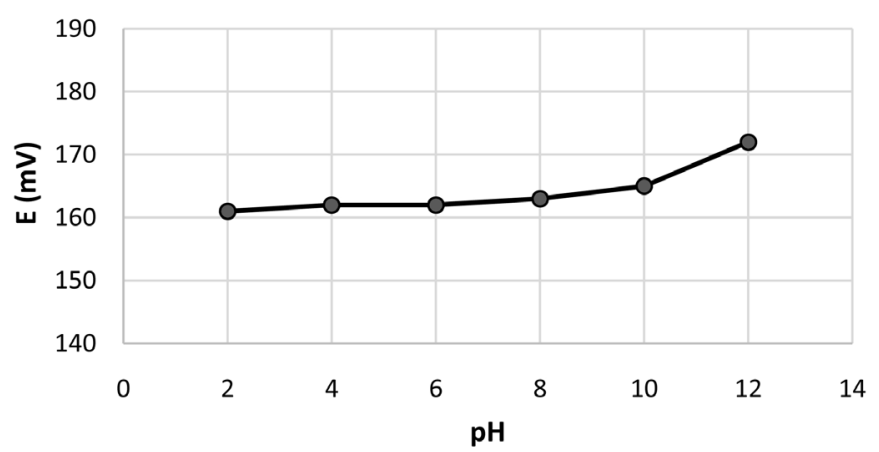

Figure 4. The $\mathrm{pH}$ dependence of $20 \% \mathrm{MoS}_{2}, 60 \% \mathrm{Ag}_{2} \mathrm{~S}$ and $20 \% \mathrm{Cu}_{2} \mathrm{~S}$ electrode in presence of $1 \times 10^{-3} \mathrm{M}$ Mo (VI).

The reason of the potential change at $\mathrm{pH}$ values higher than 9, may be because of the slight dissolution of $\mathrm{Cu}_{2} \mathrm{~S}$, oxidation of $\mathrm{Cu}$ (I) and then formation of $\mathrm{Cu}$ (II) complexes with hydroxide ion. As expected the potential increased in possitve direction with $\mathrm{pH}$ because of $\mathrm{OH}^{-}$(anion) complexes of copper (II), with negative oxidation state.

\subsection{Interferences Studies}

It usually is not possible to obtain an ISE, which is only specific for one ion. Thus, in order to achieve correct and sensitive results in analysis it is important to know the effects of all other ions in the medium. These effects are identified through selectivity coefficients. In this study mixed solutions method was used to determine selectivity coefficient, $k_{A, B}^{p o t}$ as it usually corresponds more closely to the situation in samples. In this method, solutions were prepared with a constant activity of the main ion and varying activity of interfering ion. Selectivity coefficient values were calculated via making use [16] of the below given equation:

$$
k_{\mathrm{A}, \mathrm{B}}^{\text {pot }} \times a_{\mathrm{B}}^{n_{\mathrm{A}} / n_{\mathrm{B}}}=a_{\mathrm{A}}\left\{\operatorname{antilog}\left[\left(E_{1}-E_{2}\right) / S\right]\right\}-a_{\mathrm{A}}
$$

Here, $S=2.303 R T / n A F$ (the slope of borate electrode), $a_{\mathrm{A}}$ is the activity of the primary ion (here borate), $a_{\mathrm{B}}$ the activity of the interfering ion, $E_{1}$ the potential measured when only $\mathrm{A}$ is present, $E_{2}$ the potential responsive to the primary ion in the presence of interfering ion, the selectivity coefficient, $\left(k_{\mathrm{A}, \mathrm{B}}^{p o t}\right)$ and $n_{\mathrm{A}}, n_{\mathrm{B}}$ are the charges of A (molybdenum) and B (interfering ion).

Possible interferences by a number of anions, $\mathrm{Cl}^{-}, \mathrm{Br}^{-}, \mathrm{NO}_{3}^{-}, \mathrm{H}_{2} \mathrm{PO}_{4}^{-}, \mathrm{SO}_{4}^{2-}$ and some cations, $\mathrm{K}^{+}, \mathrm{Na}^{+}, \mathrm{Cu}^{2+}, \mathrm{Ag}^{+}, \mathrm{Ca}^{2+}$ were studied. In this work interfering ion was added into $0.1 \mathrm{M} \mathrm{NaNO}_{3}$, containing $10^{-5} \mathrm{M}$ molybdenum solution, so that the interfering ion concentration was $10^{-2}-10^{-5} \mathrm{M}$, and after each addition, the change of potential was measured.

The potentials obtained at different concentrations of interfering ions are plotted against concentrations as shown in Figure 5 for cations and in Figure 6 for anions. For comparison the curve obtained for molybdenum is also given in the same figure. 


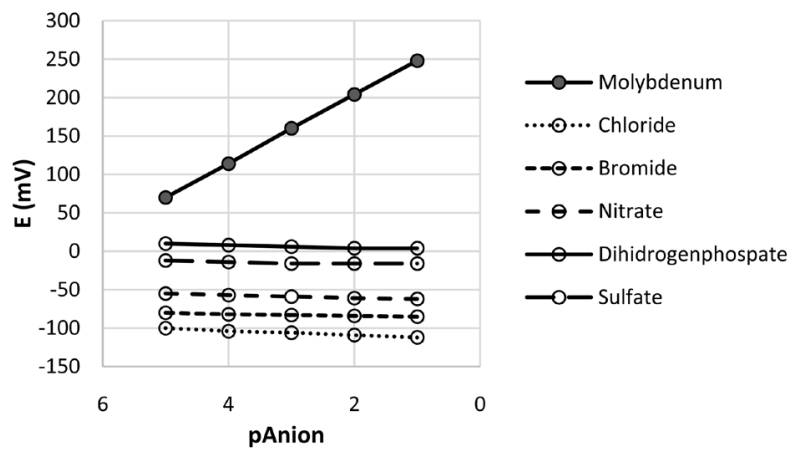

Figure 5. The response of electrode against some anions in the presence of $1 \times 10^{-5} \mathrm{M} \mathrm{Mo}$ (VI) $\left(20 \% \mathrm{MoS}_{2}, 60 \% \mathrm{Ag}_{2} \mathrm{~S}, 20 \% \mathrm{Cu}_{2} \mathrm{~S}\right)$.

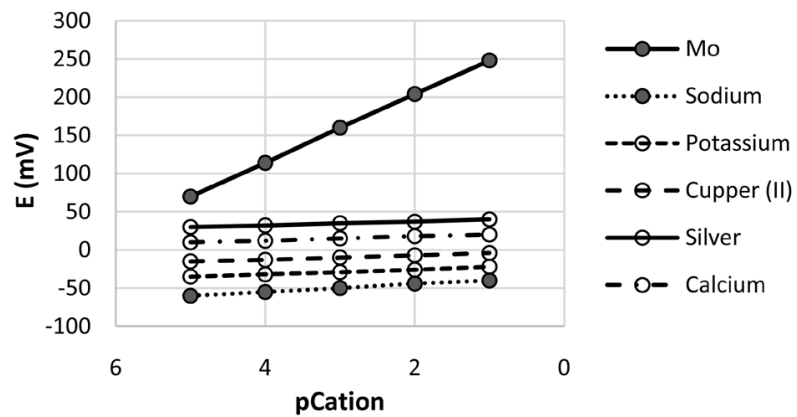

Figure 6. The response of electrode against some cations in the presence of $1 \times 10^{-5} \mathrm{M}$ Mo (VI) (20\% $\left.\mathrm{MoS}_{2}, 60 \% \mathrm{Ag}_{2} \mathrm{~S}, 20 \% \mathrm{Cu}_{2} \mathrm{~S}\right)$.

While no interference was observed for sodium, potassium, calcium and copper, slight interference was observed for silver ions. As can be seen nearly no interference was observed for chloride, nitrate, sulfate and dihydrogen phosphate ions. Only, bromide has shown slight effect when its concentration was about $10^{-3} \mathrm{M}$. The selectivity coefficients calculated for above mentioned ions are summarized in Table 2.

\subsection{Determination of Molybdenum in Spinach}

For this purpose, first wet spinach leaves were dried until constant weight at $110^{\circ} \mathrm{C}$. A sample of about $1 \mathrm{~g}$ was taken and was left wait in $15 \mathrm{ml}$ of $\mathrm{HNO}_{3}$ for a few days for digestion. Then it was evaporated until about $1 \mathrm{ml}$ was left and then it is diluted into $10 \mathrm{ml}$ in a volumetric flask with distilled water. The digested and diluted sample was kept in Teflon bottle in refrigerator [17] [18].

For the determination of molybdenum, first the potential of $20 \mathrm{ml}$ of $0.1 \mathrm{M}$ $\mathrm{NaNO}_{3}$ is measured using molybdenum ion selective electrode.

Then, appropriate volumes of spinach samples were added and once more potential was measured. (In case of lower concentrations of molybdenum, Na$\mathrm{NO}_{3}$ had to be added into larger volumes of spinach sample).

The molybdenum (as B) content of this spinach was determined by standard additions, as can be seen from Table 3. To check the validity of the method, the same spianch sample was analyzed also by differential pulse polarographic (DPP) 
Table 2. Selectivity coefficients ( $k_{\mathrm{A}, \mathrm{B}}^{\text {pot }}$ ) for the borate electrode in mixed solutions ${ }^{\mathrm{a}}$ (in the presence of $1 \times 10^{-5} \mathrm{M}$ molybdenum).

\begin{tabular}{cccc}
\hline $\mathrm{B}(\text { anions })^{\mathrm{b}}$ & $k_{\mathrm{A}, \mathrm{B}}^{\text {pot }}$ & $\mathrm{B}(\text { cations })^{\mathrm{b}}$ & $k_{\mathrm{A}, \mathrm{B}}^{\text {pot }}$ \\
\hline $\mathrm{Cl}^{-}$ & $2 \times 10^{-4}$ & $\mathrm{Na}^{+}$ & $1 \times 10^{-4}$ \\
$\mathrm{Br}^{-}$ & $1 \times 10^{-4}$ & $\mathrm{~K}^{+}$ & $2 \times 10^{-4}$ \\
$\mathrm{NO}_{3}^{-}$ & $1 \times 10^{-4}$ & $\mathrm{Ag}^{+}$ & $2 \times 10^{-4}$ \\
$\mathrm{SO}_{4}^{2-}$ & $2 \times 10^{-5}$ & $\mathrm{Cu}^{2+}$ & $3 \times 10^{-5}$ \\
$\mathrm{H}_{2} \mathrm{PO}_{4}^{-}$ & $1 \times 10^{-5}$ & $\mathrm{Ca}^{2+}$ & $3 \times 10^{-5}$ \\
\hline
\end{tabular}

${ }^{\mathrm{a}} \mathrm{A}$ : Molybdenum. ${ }^{\mathrm{b}} \mathrm{B}$ : Interfering ion.

Table 3. Determination of molybdenum ion in spinach samples.

\begin{tabular}{cccc}
\hline Sample & DP Polarography $(\mu \mathrm{g} / \mathrm{g})$ & Molybdenum electrode $(\mu \mathrm{g} / \mathrm{g})$ & $\mathrm{t}_{\text {experimental }} \mathrm{t}_{\text {critical }}=2.015$ \\
\hline Spinach & $43 \pm 2$ & $42 \pm 2$ & 0.819 \\
\hline $95 \% \mathrm{CI}$ and $\mathrm{N}=5$. & & &
\end{tabular}

method [12]. Good agreement was obtained between two different methods. Molybdenum sample was also determined using the newly established electrode. The results are summarized in Table 3 together with the result obtained using DPP.

\section{Conclusion}

Although there are many investigations about pellet electrodes prepared from solid salts, none of these were subject for molybdenum ion determination. In this work a new molybdenum ion selective electrode using solid salts of $\mathrm{MoS}_{2}$, $\mathrm{Ag}_{2} \mathrm{~S}$ and $\mathrm{Cu}_{2} \mathrm{~S}$ has been prepared. The preparation of the electrode is simple; it displays very good performance in regard to reproducibility, sensitivity and lifetime. The slope of the linear portion $\left(1 \times 10^{-1}-1 \times 10^{-5} \mathrm{M}\right)$ was $45 \pm 2 \mathrm{mV} /$ decade change in molybdenum ion. This electrode displayed very good selectivity for molybdenum ion with respect to $\mathrm{Cl}^{-}, \mathrm{Br}^{-}, \mathrm{NO}_{3}^{-}, \mathrm{SO}_{4}^{2-}, \mathrm{H}_{2} \mathrm{PO}_{4}^{-}$anions and $\mathrm{K}^{+}$, $\mathrm{Na}^{+}, \mathrm{Cu}^{2+}, \mathrm{Ca}^{2+}$ cations. It was found that only $\mathrm{Ag}^{+}$had a small interference effect.

\section{Acknowledgements}

This is my post-doctoral work. My research is focused on the developments of ion selective electrodes and trace element determinations in real substances.

\section{Conflicts of Interest}

The author declares no conflicts of interest.

\section{References}

[1] Kataoka, M., Nishimura, K. and Kambaral, T. (1983) Catalytic Determination of Molybdenum(VI) by Means of an Iodide Ion-Selective Electrode and a Landolt-Type 
Hydrogen Peroxide-Iodide Reaction. Talanta, 30, 941-944.

https://doi.org/10.1016/0039-9140(83)80217-3

[2] Altinata, A. and Pekin, B. (1973) Determination of Molybdenum and Tungsten with Iodide Activity Electrode. Analytical Letters, 6, 667-673.

https://doi.org/10.1080/00032717308058719

[3] Ganjalia, M.R., Norouzia, P., Ghomib, M. and Salavati-Niasaric, M. (2006) Highly Selective and Sensitive Monohydrogen Phosphate Membrane Sensor Based on Molybdenum Acetylacetonate. Analytica Chimica Acta, 267, 196-201. https://doi.org/10.1016/j.aca.2006.03.026

[4] ShukUlrich, P. and Greenblatt, G.M. (2002) Ion-Selective Sensors Based on Molybdenum Bronzes. Journal of Solid State Electrochemistry, 6, 374-383.

https://doi.org/10.1007/s100080100249

[5] Ghanei-Motlagh, M., Taher, M.A., Ahmadi, K. and Sheikhshoaie, I. (2011) Iodide Selective Membrane Electrodes Based on a Molybdenum-Salenas a Neutral Carrier. Materials Science and Engineering: C, 31, 1625-1631.

https://doi.org/10.1016/j.msec.2011.06.006

[6] Zeng, X., Yu, S., Yuan, Q. and Qin, W. (2016) Solid-Contact K+ -Selective Electrode Based on Three-Dimensional Molybdenum Sulfide Nanoflowers as Ion-to-Electron Transducer. Sensors and Actuators B: Chemical, 234, 80-83. https://doi.org/10.1016/j.snb.2016.04.153

[7] Ekmekçi, G. and Somer, G. (1999) Preparation and Properties of Solid State Selenite Ion Selective Electrodes and Their Applications. Talanta, 49, 91-98.

https://doi.org/10.1016/S0039-9140(98)00350-6

[8] Ekmekçi, G., Kalaycı, S. and Somer, G. (2004) A Solid-State Hydroxide Ion Selective Electrode for the Measurement of High pH Values. Sensors and Actuators: B, 101, 260-264. https://doi.org/10.1016/j.snb.2004.03.012

[9] Somer, G., Kalaycı, S. and Başak, I. (2010) Preparation of a New Solid State Fluoride Ion Selective Electrode and Application. Talanta, 80, 1129-1132. https://doi.org/10.1016/j.talanta.2009.08.037

[10] Somer, G., Kalayc1, S., Doğan, M. and Şendil, O. (2011) Preparation and Properties of a New Solid State Borate Ion Selective Electrode and Its Application. Talanta, 85, 1461-1465. https://doi.org/10.1016/j.talanta.2011.06.028

[11] Somer, G. and Ünal, Ü. (2004) A New and Direct Method for the Trace Element Determination in Cauliflower by Differential Pulse Polarography. Talanta, 62, 323-328. https://doi.org/10.1016/j.talanta.2003.07.018

[12] Somer, G., Kalayc1, S. and Şendil, O. (2016) A New and Direct Method for the Determination of Trace Elements in Spinach Using Differential Pulse Polarography. Journal of Electroanalytical Chemistry, 778, 49-52. https://doi.org/10.1016/j.jelechem.2016.07.041

[13] Burba, P. and Willmer, B. (1986) Trace Determination of Molybdenum and Vanadium in Natural Waters by Means of Atomic Spectroscopy (AAS, ICP-OES) after Preconcentration. Fresenius' Zeitschrift für Analytische Chemie, 324, 298-299. https://doi.org/10.1007/BF00487941

[14] Gürkan, R., Korkmaz, S. and Altunay, N. (2015) Preconcentration and Determination of Vanadium and Molybdenum in Milk, Vegetables and Foodstuffs by Ultrasonic-Thermostatic-Assisted Cloud Point Extraction Coupled to Flame Atomic Absorption Spectrometry. Talanta, 155, 38-46. https://doi.org/10.1016/j.talanta.2016.04.012

[15] Barros, J.A.V.A., Virgilio, A., Schiavo, D. and Nóbrega, J.A. (2017) Determination 
of Ultra-Tracelevels of Mo in Plants by Inductively Coupled Plasma Tandem Mass Spectrometry (ICP-MS/MS). Microchemical Journal, 133, 567-571. https://doi.org/10.1016/j.microc.2017.04.037

[16] Srinivasan, K. and Rechnitz, G.A. (1969) Selectivity Studies on Liquid Membrane, Ion-Selective Electrodes. Analytical Chemistry, 41, 1203-1208.

https://doi.org/10.1021/ac60279a014

[17] Somer, G., Nakışcı, A., Kalaycı, S. and Şahin, F. (2006) Trace Element Determination in Brassica Oleraceae var. Acephale by Differential Pulse Polarography. Turkish Journal of Chemistry, 30, 419-423.

[18] Unal, U. and Somer, G. (2009) Indirect Determination of Trace Tetraborate by Differential Pulse Polarography Using Its Copper Complex and Application to Waste and Drinking Water. Electroanalysis, 21, 2234-2240.

https://doi.org/10.1002/elan.200904674 